Dicle Tıp Dergisi / Dicle Med J (2019) 46 (2) : 355 - 360

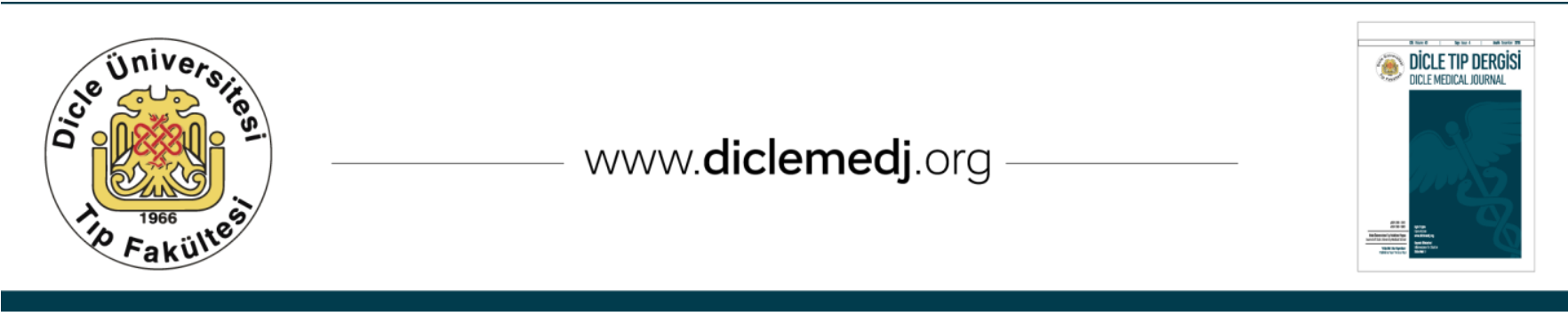

Özgün Araștırma / Original Article

\title{
Evaluation of The Occupational Exposures Among Residents in a Tertiary Hospital
}

\author{
Heval Can Bilek ${ }^{1}$, Hakan Leblebicioğlu ${ }^{2}$ \\ 1 Ondokuz Mayıs University, Faculty of Medicine, Infectious Diseases and Clinical Microbiology, Samsun, Turkey ORCID: 0000-0002-4330-3293 \\ 2 Samsun Liv Hospital, Infectious Diseases and Clinical Microbiology, Samsun, Turkey ORCID:0000-0002-6033-8543
}

Received: 21.03.2019; Revised: 13.05.2019; Accepted: 14.05.2019

\begin{abstract}
Objective: Occupational exposures, can lead to decreased employee productivity, increased cost of health expenses and temporary or permanent suspension from working life. The most common cause of illness and death due to occupational exposures are blood-borne infections. In this study, it was aimed to evaluate the occupational exposures among residents in a tertiary hospital that provides health care in a region where the Crimean-Congo hemorrhagic fever disease is endemic.

Methods: A questionnaire consisting of 18 questions distributed to the residents of internal, surgery and basic medical sciences working at a tertiary hospital between February and March 2016. In the relevant departments, 330 residents were reached and 210 of them answered the questionnaire.

Results: In our study; $160(76.2 \%)$ of the residents reported occupational exposure in their working life and $74(35.2 \%)$ of them had occupational exposure in the recent year. The incidence of occupational exposures in the comparison of medical sciences was statistically higher in surgical sciences. Of the participants working in the surgical sciences, 22(42.3\%) residents stated that they received in-service training in the recent year on the prevention, treatment, and follow-up of occupational exposures. Among participants who had occupational exposure in recent year, only $8(11.4 \%)$ residents declared that they have reported about their exposure.

Conclusion: To prevent occupational exposures, it is required to make more effective interventions of protection measures in the light of current information and assessment of post-exposure attitudes of residents. We hope that the risks that our study has identified may help to take necessary preventive measures.
\end{abstract}

Keywords: Resident, tertiary hospital, occupational exposure. 


\section{Üçüncü Basamak Bir Hastanede Çalışan Uzmanlık Öğrencilerinin Mesleki Maruziyetlerinin Değerlendirilmesi}

\section{Öz}

Giriş: Mesleki maruziyetler, sağlık çalışanlarını iş yaşamından geçici veya kalıcı olarak uzaklaştırmakta, iş verimliliğini düşürmekte ve kurumların sağlık kaynaklı maliyet giderlerini arttırmaktadır. Sağlık çalışanları açısından mesleki maruziyet kaynaklı en sık hastalık ve ölüm nedeni enfeksiyonlardır. Çalışmamızda, Kırım-Kongo kanamalı ateşi hastalığının endemik olduğu bir bölgede sağlık hizmeti veren üçüncü basamak bir hastanedeki uzmanlık öğrencilerinin mesleki maruziyetlerinin değerlendirilmesi amaçlanmıştır.

Yöntemler: Üçüncü basamak bir hastanede çalışan iç hastalıkları, cerrahi ve temel tıp bilimleri uzmanlık öğrencilerine ulaşılarak Şubat ve Mart 2016 tarihleri arasında dağıtılan 18 sorudan oluşan bir anketi yanıtlamaları istenmiştir. İlgili bölümlerden 330 uzmanlık öğrencisine ulaşılmış ve 210 kişi ankete katılmıştır.

Bulgular: Uzmanlık öğrencilerinden 160(\%76,2)'ı meslek yaşamları boyunca, 74 (\%35,2)'si de son bir yıl içinde mesleki maruziyet bildirdiler. Tıbbi bilimler arasında mesleki maruziyet sıklı̆̆ cerrahi bilimlerde istatistiki olarak fazla bulundu. Cerrahi bilimlerde çalışan katılımcıların 22(\%42,3)'si mesleki maruziyetlerin önlenmesi, tedavisi ve takibi ile kurumunda son bir yıl içinde hizmet içi eğitim aldığını belirtti. Son bir yıl içinde mesleki maruziyeti olan uzmanlık öğrencisinden sadece 8(\%11,4)'i maruziyet sonrası bildirimde bulunduklarını belirtmiştir.

Sonuç: Mesleki maruziyetleri önlemek için, güncel bilgiler ışığında koruma tedbirlerine etkili müdahalelerinin yapılması ve uzmanlık öğrencilerinin maruz kalma sonrası tutumlarının değerlendirilmesi gerekmektedir. Çalıșma bulgularımızın, mesleki maruziyetlerin önlenmesi için bundan sonra alınacak olan tedbirlerin tespit edilmesinde yardımcı olacağını umuyoruz.

Anahtar kelimeler: Uzmanlık öğrencisi, üçüncü basamak hastane, mesleki maruziyet

\section{INTRODUCTION}

Occupational exposures, can lead to decreased employee productivity, increased cost of health expenses and temporary or permanent suspension from working life. The most common cause of illness and death due to occupational exposures are blood-borne infections and due to their nature of occupation; health care workers always carry the risk of exposure to these infectious agents ${ }^{1}$. Transmissions within health institutions, usually occur after percutaneous or mucosal exposures to blood or body fluids of infected patients ${ }^{2}$. Besides the well-known pathogens, like hepatitis B virus (HBV), hepatitis $C$ virus (HCV) and human immunodeficiency virus (HIV) which are known to be responsible for the majority of infections as a result of occupational exposures, viral hemorrhagic fever pathogens such as Ebola or CrimeanCongo hemorrhagic fever (CCHF) can also infect healthcare workers by the same way. Turkey has been known to be endemic for CCHF since 2002, hence, CCHF virus must also be considered as one of the pathogens transmitted by occupational exposures in endemic areas. In this study, it was aimed to evaluate the occupational exposures among residents in a tertiary hospital which provides health care for patients in a region where the CCHF disease is endemic. While occupational exposures, can be prevented by appropriate interventions, studies investigating this issue may be guiding.

\section{METHODS}

A questionnaire consisting of 18 questions distributed to the residents of internal, surgery and basic medical sciences working at Ondokuz Mayıs University Hospital between February and March 2016. Questionnaire forms were filled in face-to-face interviews or given to the 
participants to be collected. The questionnaire consists of three parts according to the scope of the questions. In the first part, participants were asked about the gender, age, graduation dates and study periods in their academic science. In the same section; occupational exposures in professional life, vaccination status, and serologic profiles were also asked. In the second part participants with occupational exposures were asked about the type, location and time of their exposures. In the third section, participants were asked about their opinions on what measures may be useful in protecting against exposures. In the relevant departments, 330 residents were reached and 210 of them answered the questionnaire. The obtained data analyzed. For the statistical evaluation of proportional differences chisquare test and for the comparison of quantitative data non-parametric MannWhitney U test and Kruskal-Wallis tests were performed. This study was approved by the local ethics committee (permit no: 2168-109).

\section{RESULTS}

A total of 210 residents, of them 110 male, 100 female, participated in the study. 148 of the participants were working in internal medicine, 52 in surgical departments and 10 in basic sciences. The average age of participating men was 30.3 , and female was 29.7 years. The mean age of the participants was $29.9 \pm 3.6 \mathrm{SD}$. (Table 1)

Table 1: Participants' gender features according to their academic sciences.

\begin{tabular}{|l|c|c|c|}
\hline & Internal Sciences & Surgical Sciences & Basic Sciences \\
\cline { 2 - 4 } & $\begin{array}{c}\text { Number(N) } \\
/ \text { Percent }(\%)\end{array}$ & $\mathrm{N} / \%$ & $\mathrm{~N} / \%$ \\
\hline Male & $74(50 \%)$ & $30(57.7 \%)$ & $6(60 \%)$ \\
\hline Female & $74(50 \%)$ & $22(42.3 \%)$ & $4(40 \%)$ \\
\hline Total & $148(100 \%)$ & $52(100 \%)$ & $10(100 \%)$ \\
\hline
\end{tabular}

Of the residents $79(71.8 \%)$ male and 81 (81\%) female, in the total, 160 (76.2\%) participants reported occupational exposure in their working life. 35 (31.8\%) male and 39 (39\%) female, in the total $74(35.2 \%)$ of the residents reported occupational exposure in the recent year. There were no significant differences when we evaluated the occupational exposure rates in working life and in recent year by gender $(p=0.128, p=0.277)$. (Table 2$)$.

Table 2: Occupational exposure rates in working life and in recent year by gender.

\begin{tabular}{|l|c|c|}
\hline \multirow{2}{*}{ Residents } & Working life & Recent year \\
\cline { 2 - 3 } & $\mathrm{N} / \%$ & $\mathrm{~N} / \%$ \\
\hline Male & $79(71.8 \%)$ & $35(31.8 \%)$ \\
\hline Female & $81(81 \%)$ & $39(39 \%)$ \\
\hline Total & $160(76.2 \%)$ & $74(35.2 \%)$ \\
\hline
\end{tabular}

Among residents, $42(80.8 \%)$ participants in the surgical sciences, 64 (43.2\%) participants in the internal sciences and 2 (20\%) participants in the basic sciences indicated that each working day they perform medical procedures, requiring the risk of exposure to patients' blood or other body fluids. In the binary comparisons of medical units, the highest incidence of performing medical procedures was found in surgical units. This difference was statistically significant $(\mathrm{p}<0.005)$.

Of the 28 (53.8\%) participants in the surgical sciences, 44 (29.7\%) in the internal sciences and $2(20 \%)$ in the basic sciences reported that they had occupational exposure in recent year. In binary comparisons; the rates of occupational exposures in surgical sciences was statistically higher than in internal sciences (p<0.05). (Table 3)

Of the 74 participants who had occupational exposure in recent year, 70 of them responded whether if they reported the exposure. Of them, 
only $8(11.4 \%)$ residents declared that they have reported about their exposure. There was no statistical relationship between the attitude of reporting exposure and gender, age, duration of study in academic unit and year of residency $(p=1)$.

Table 3: Incidence of performing medical procedures and occupational exposure rates.

\begin{tabular}{|l|c|c|}
\hline \multirow{2}{*}{ Sciences } & $\begin{array}{c}\text { Performing medical } \\
\text { procedures each } \\
\text { working day }\end{array}$ & $\begin{array}{c}\text { Occupational exposure in } \\
\text { recent year }\end{array}$ \\
\cline { 2 - 3 } & $\mathrm{N} / \%$ & $\mathrm{~N} / \%$ \\
\hline Surgical & $42(80.8 \%)$ & $28(53.8 \%)$ \\
\hline Internal & $64(43.2 \%)$ & $44(29.7 \%)$ \\
\hline Basic & $2(20 \%)$ & $2(20 \%)$ \\
\hline
\end{tabular}

The participants who did not report their exposure were asked about the reasons for not reporting; 34 (56.7\%) of them stated that they thought that there was no risk, 16 (26.7\%) stated that they did not know that they have to report, $10(16.6 \%)$ participants stated different reasons.

Of the 68 (45.9\%) participants working in the internal sciences, $22 \quad(42.3 \%)$ of the participants working in the surgical sciences and $6(60 \%)$ of the participants working in the basic sciences stated that they received inservice training in the recent year on the prevention, treatment, and follow-up of occupational exposures. There was no significant difference between the ratio of receiving in-service training among medical sciences $(\mathrm{p}=0.586)$.

Knowing the serologic status of the residents in terms of HBV, HCV and HIV infection was asked in the questionnaire. It was found that knowing the serological status was significantly higher among female residents (HBV $\mathrm{p}<0.05$, for $\mathrm{HCV}$ and HIV p<0.001) (Table 4).
Table 4: Knowing the serologic status among residents by gender.

\begin{tabular}{|l|c|c|c|}
\hline \multirow{2}{*}{} & HBV & HCV & HIV \\
\cline { 2 - 4 } & N / \% & N / \% & N / \% \\
\hline Male & $101(91.8 \%)$ & $86(78.1 \%)$ & $81(73.6 \%)$ \\
\hline Female & $97(97.9 \%)$ & $93(93.9 \%)$ & $93(93.9 \%)$ \\
\hline Total & $198(94.2 \%)$ & $179(85.2 \%)$ & $174(82.8 \%)$ \\
\hline
\end{tabular}

In the questionnaire the measure/measures to be taken to reduce occupational exposures were asked to the residents; $180(85.7 \%)$ of the participants stated that blood collection procedure should be performed by specially trained/experienced personnel, 175 (83.6\%) of them stated that regular in-service training should be provided with regard to prevention and follow-up of exposures; 174 (82.8\%) stated that more protective materials and equipment to be maintained / easily accessible; 167 (79.5\%) of them stated that the workload should be arranged in favor of employees and $148(70.4 \%)$ of them stated that they want working hours to be reduced. 114 (54.3\%) of the participants marked all of the options.

\section{DISCUSSION}

Occupational exposures rates were questioned in different studies carried out from our country and abroad and different ratios were determined during these studies. Despite the differences due to the demographic characteristics of the studies, the exposure rates of all healthcare professionals and residents were quite high. In our study; 160 (76.2\%) of the residents reported occupational exposure in their working life and 74 (35.2\%) of them had occupational exposure in the recent year. Kisioglu et all., Dikmen et all. and Cilız et all. reported the rate of sharp injuries in the last twelve months among residents as $40.8 \%, 64.1 \%, 64.4 \%$, respectively3,4.5. In a survey of 612 medical doctors in Switzerland, the incidence of sharp injuries in invasive 
procedures was found to be $36.9 \%$ over the past year6. In a study of a reference hospital in Beijing between April and May 2004, 64.7\% of medical doctors reported that they had at least one exposure to blood or body fluids in the previous year ${ }^{7}$. Exposure rates will be higher when participants of the study are in need of invasive procedures and therefore have a higher risk of injury. We believe that different exposure rates are due to the fact that the participants are either unspecified in their sciences or that the participants constituting the study universe are clustered in surgical and or in other sciences.

In our study, the incidence of occupational exposures in the comparison of medical sciences was statistically higher in surgical sciences. Azap et al. determined that surgical residents have 5.5 times $(44 \%$, 8\%, respectively) much more sharp object injuries than residents in the internal sciences ${ }^{8}$. In the study of Pournaras et al. it was found that the medical doctors working in surgical sciences are injured more than those working in basic and internal medical sciences ${ }^{9}$.

In similar studies conducted in our country, the incidence of occupational exposure in surgical medical sciences has been found much more in proportion to those working in the internal medical sciences and basic medical sciences $3,10,11$. The high incidence of invasive procedures performed by residents in surgical sciences, both inward, at emergency services and in operating rooms explains the higher rates of injuries when compared to other sciences. The findings of our study also support this result.

In our study, non- reporting rates of exposures are generally considered very high. Only $8(11.4 \%)$ of the residents stated that they reported after exposure. In a similar study, the reporting rate for health care workers was determined as $15.6 \%$ and for medical doctors, it was $8.3 \%^{11}$. Yoldaş et al. stated in their study that $21 \%$ of those who experienced exposure had reported their exposures to the hospital administration ${ }^{12}$. In a study conducted in Beijing, China, exposures were reported by only $2.2 \%$ of the medical doctors ${ }^{7}$. The participants who did not report their exposures mostly stated that they thought that there was no risk and that they did not know that they have to report.

These reasons stated above have suggested that there is a lack of education and knowledge even among medical doctors who are expected to be more knowledgeable about this issue than other health professionals. The fact that only less than half $(42.3 \%)$ of the medical doctors working in the surgical sciences have received in-service training within the last year, indicates a lack of education and knowledge among residents.

Among female residents, the rate of knowing the HBV, HCV and HIV serologic status was found higher and determined statistically significant. This may be related to the routine evaluation of these serologic markers in pregnancy and delivery related clinical followups of female residents. Being aware of their serological status in terms of viral diseases among health care workers is important for the rapid application of prophylaxis measures after exposure. Therefore, we believe that it is important to know the serological profile in terms of infectious diseases profile at the beginning of professional life.

The views of the participants on the measures to be taken in order to prevent occupational exposures generally focused on reducing their workload, receiving in-service training and maintenance of protective equipment. We agree with these opinions as common in all medical units. A reduced or appropriately distributed workload can be effective in reducing professional accidents due to the heavy workload. It is also important to create 
continuous awareness about occupational exposures with in-service training.

\section{CONCLUSION}

Residents encounter the risk of exposure to infectious agents in their day-to-day practice, which is the nature of their profession. It is important to know the prevalence and risk factors of occupational exposures among residents working in a hospital which is serving in a region endemic for $\mathrm{CCHF}$.

As shown in our study, occupational exposure rates were quite high. At the same time, detection of the lack of in-service training and the low rate of reporting of occupational exposures were also important findings of the study and are issues of concern. For this purpose, to prevent occupational exposures, it is required to make more effective interventions of protection measures in the light of current information, and assessment of post-exposure attitudes of residents. We hope that the risks that our study has identified may help to take necessary preventive measures.

Conflicts of interest: The authors have no conflict of interests to declare.

Financial Disclosure: The authors declared that this study has received no financial support.

\section{REFERENCES}

1. Uğurlu N, Yılmaz B, Karabacak F. İki farklı hastanede çalışan hemşirelerin mesleki risk faktörlerinin belirlenmesi. Istanbul Univ Florence Nightingale Hemsire Yo Derg 2010; 18: 19-25.

2. Beltrami EM, Williams IT, Shapiro CN, Chamberland ME. Risk and management of blood-borne infections in health care workers. Clin Microbiol Rev 2000; 13: 385407.

3. Kişioğlu AN, Öztürk M, Uskun ME, Kırbıyık S. Bir Üniversite Hastanesi Sağlık Personelinde Kesici Delici Yaralanma Epidemiyolojisi ve Korunmaya Yönelik Tutum ve Davranışlar. T Klin Tıp Bilimleri 2002; 22: 390-6.

4. Dikmen AU, Medeni V, Uslu İ, Aycan S. Ankara'da Bir Üniversite Hastanesinde Çalışan Sağlık Personelinin Geçirdiğini İfade Ettiği İş̧ Kazalarının Değerlendirilmesi. Ttb Mesl Saglik Guven Derg 2014: 22-9.

5. Cılız N, Gazi H, Ecemiș T, et all. Sağlık Calıșanlarında Kızamık, Kızamıkcık, Kabakulak, Suciceği, Difteri, Tetanos ve Hepatit B seroprevalansı. KLIMIK Derg 2013; 26: 26-30.

6. Voidea C, Darlinga KEA, Kenfak-Foguenaa A, et all. Underreporting of needlestick and sharps injuries among healthcare workers in a Swiss University Hospital. Swiss Med Wkly 2012; 142: 13523.

7. Zhang M, Wang H, Miao J, et all. Occupational exposure to blood and body fluids among health care workers in a general hospital, China. Am. J. Ind. Med 2009; 52: 8998.

8. Azap A, Ergönül Ö, Memikoğlu KO, et all. Occupational exposure to blood and body fluids among health care workers in Ankara, Turkey. Am J Infect Control 2005; 33: 48-52.

9. Pournaras S, Tsakris A, Mandraveli K, et all. Reported needlestick and sharp injuries among health-care workers in a Greek general hospital. OccupMed 1999; 49: 423-6.

10. Erol S, Özkurt Z, Ertek M, Kadanalı A, Taşyaran MA. Sağlık çalışanlarında kan ve vücut sıvılarıyla olan mesleki temaslar. Hastan İnfeks Derg 2005; 9: 101-6.

11. Gülay M. Uludağ Üniversitesi sağllk kuruluşlarında çalışan tıbbi personelin ve temizlik personelinin kesici delici alet yaralanmalarına maruziyet durumu (Tez). Bursa: Uludağ Üniversitesi Tıp Fakültesi; 2010.

12. Yoldaș Ö, Bulut A, Ertürk E, et all. Sağllk Çalışanlarında Enfekte Kan ve Vücut Sivılarına Maruziyet Riskinin Belirlenmesi. Kocatepe Tip Derg 2015; 15: 297-300. 